establishment of national colleges of technology wherever industry is prepared to co-operate, and five are already open. A further one at Bradford for wool has been approved in principle, as well as two others. Other problems in the higher technological field are being considered by the National Advisory Council on Education in Industry and Commerce in congultation with the University Grants Committee. 8y:

\section{University Entrance Awards and Scholarships}

Wiтн regard to university awards and scholarships, Mr. Tomling ponounced that he proposes to carry out the recifmendations made by the working party on th 4 ject in Chapter 4 of its report. These re or henlations, which are to be put into effect fo thwith, include revision of the income scale for parental contributions on more adequate and up-todate lines, the assessment of grants and contributions on the basis of a full year, and larger children's and education allowances. There is also to be an increase by one hundred this year in the number of State scholarships. The vice-chancellors of universities and the local education authorities are already in consultation about a procedure for local awards under which full weight will be given to the recommendations of universities on the merits of students. $\mathrm{He}$ hoped in the future to tidy up the grants to intending teachers; but this must be done by stages. Before long he hoped to abolish the system of four-year grants based on an undertaking by the individual teacher. Mr. Tomlinson did not think that there is any evidence that the standard of students leaving the schools has declined.

The Minister has thus accepted substantially the recommendations made earlier in a report "Entrance to the Universities" prepared by the Education Advisory Committee of the Workers' Educational Association and adopted by the annual conference in October 1948. A "Comment" on the working party's proposals now appended to this report expresses the view that, if fully implemented, the working party's report should provide the best means of discovering the real scale of the demand for university places and how far the supply is adequate. It should pave and not block the way for the inquiry into a long. term policy with regard to the universities which was urged in the report from the Workers' Educational Association's committee and endorsed by the conference. These questions, it was urged, should be investigated by a committee consisting of representatives of the universities, the Ministry of Education, the Treasury, teachers, industry and men and women representatives of other aspects of our national life. Besides the number of university places to be provided and the question of the selection of university students, the function of the university in the national life of Britain, the length of the university course, the proportion of general and special education in a first degree, the recruitment and training of university teachers, adult students at universities and the interchange of students with the Dominions and overseas generally were $r$ pommended for investigation.

\section{Electrik Power Engineering in Germany during the War}

B.I.O.S. Oyprall Report No. 11 ("Electric Power Engineering Gefefmany during the Period 1939194.." P. 56. London: H.M. Stationery Office. 1s. If f f views developments in electrical power practice trder five headings: turbines, generators and motors; switchgear, transformers and other equipment for the transmission system; power cables ; mercury-arc rectifiers ; batteries and battery traction. Each section of this publication, which, in fact, epitomizes a group of individual summary reports, presents a picture of the position in that field in Germany at the end of the War, makes some assessment of the most significant developments and contrasts the German position with that existing in Great Britain. This last-mentioned feature adds greatly to the value of the document. The report concludes with an extensive list of references to other detailed reports and to original German documents, and is not only an informative record but also constitutes a valuable critical comparison of British and German development. It merits the attention of all concerned with either the manufacturing or the supply side of the electrical industry.

\section{Astronomy Gallery at the Science Museum, Kensington}

THE Astroxomy Gallery at the Science Museum, South Kensington, London, S.W.7, is now fully open to the public after having been closed since the outbreak of the War. Among the many exhibits once again on view are historic telescopes, models of the solar system including an orrery made for George III, sundials, sextants and several historic globes. An exhibit now shown for the first time is one presented by H.M. The King - a globe upon which is engraved a representation of the visible surface of the moon. Constructed by John Russell, R.A., in 1797, the globe is known as a selenographia, and it is supported in a complicated mounting upon which the motions of the moon can be demonstrated. In the course of a month the moon, as seen from the earth, appears to oscillate slightly, and a small part of the surface, first on one edge and then on the other, is exposed. The result is that 59 per cent of the surface can be observed; but the other 41 per cent has never been seen. The mechanical mounting of the selenographia enables these oscillations, or 'librations', of the moon to be demonstrated in detail.

\section{Training for Management}

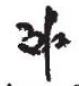

AN interesting attempt to provide training for management or spudents who have had little or no industrial exp. Hence has recently been announced by the Ifeich College of Technology and Commerce. Whe fourse has been arranged to combine courses of sthely with the acquiring of practical experience. All students have to be nominated by a firm or organisation with whom they are working, and are required to attend at the School of Commerce for three separate months of residence spread over a total period of thirteen months. During the remaining ten months a course of directed reading is prescribed, suitable study notes being provided by the College; each student is required to attend the College for tutorial sessions on two occasions during each reading period. The course itself will cover the Common Intermediate Examination in Management and will allow the student to sit for the National Diploma in Management after a further two years of part-time study.

\section{Experimental Cel/ Research}

A NEW journal entitled Experimental Cell Research is being jssued under the auspices of the International Society for Cell Biology. It will publish papers dealing with experimental analysis of the 